\title{
Efektifitas Pemberian Terapi Pursed Lips Breathing Terhadap Status Oksigenasi Anak Dengan Pneumonia
}

\author{
Yunita Muliasari ${ }^{a}$, Iin Indrawati ${ }^{a}$ \\ ${ }^{a}$ STIKes Baiturrahim, JL.Prof.M. Yamin No. 35, Jambi, 36135, Indonesia \\ e-mail korespondensi: umi.afiqahmz@gmail.com
}

\begin{abstract}
Background: Pneumonia is the second most common disease that causes death in children under five in the world. Symptoms that appear in the case of Pneumonia are acute respiratory problems that need to be handled appropriately. The aim of this research are to identify the effect of pursed lips breathing therapy through tongue blowing activity on the oxygenation status of preschoolers with Pneumonia. Method: The sampling technique is purposive random sampling with 36 people consisting of 18 intervention groups and 18 control groups. Data were analyzed using univariate and bivariate tests. Result: The results showed a significant difference between oxygenation status before and after intervention with tongue blowing therapy (PLB), namely $\mathrm{p}=0.045$ on respiratory frequency (RR) and $\mathrm{p}=0.037$ to saturation oxygen. Recommendation: The results of this study can add alternatives to independent nurse interventions in dealing with pediatric patients who have pneumonia or with oxygenation disorders.
\end{abstract}

Key word: Pursed lips breathing (PLB), preschool children, Pneumonia

\begin{abstract}
Abstrak
Latar belakang: Pneumonia merupakan penyakit terbanyak kedua yang menyebabkan kematian pada anak balita di dunia. Gejala yang muncul pada kasus pneumonia merupakan masalah pernapasan akut yang perlu ditangani dengan tepat. Tujuan penelitian ini untuk mengidentifikasi pengaruh pemberian terapi pursed lips breathing melalui aktivitas bermain tiup lidah terhadap status oksigenasi anak usia prasekolah yang mengalami pneumonia. Metode: teknik pengambilan sampel dengan purposive random sampling sebanyak 36 orang yang terdiri dari 18 kelompok intervensi dan 18 kelompok kontrol. Data dianalisis menggunakan uji univariat dan bivariat. Hasil penelitian menunjukkan terdapat perbedaan yang bermakna antara status oksigenasi sebelum dan sesudah diberikan intervensi dengan terapi tiupan lidah (PLB), yaitu $\mathrm{p}=0,045$ terhadap frekuensi pernapasan (RR) dan $\mathrm{p}=0,037$ terhadap saturasi oksigen. Rekomendasi: Hasil penelitian ini dapat menambah alternatif intervensi mandiri perawat dalam mengatasi pasien anak yang mengalami pneumonia ataupun dengan gangguan oksigenasi.
\end{abstract}

Kata kunci: Pursed lips breathing (PLB), anak usia prasekolah, Pneumonia

\section{PENDAHULUAN}

Pneumonia adalah inflamasi parenkim paru pada alveolus dan jaringan interstisial yang disebabkan oleh bakteri, dengan gejala demam tinggi disertai batuk berdahak, napas cepat (frekuensi napas $>50 \mathrm{x} /$ menit), sesak, dan gejala lainnya (sakit kepala, gelisah, nafsu makan berkurang). World Health Organization (WHO) mendefinisikan Pneumonia hanya berdasarkan penemuan klinis yang didapat dari hasil inspeksi dan frekuensi pernapasan (Departemen Ilmu Kesehatan Anak RSCM, 2015).

Insiden Pneumonia pada anak $<5$ tahun di negara berkembang lebih tinggi bila dibandingkan dengan negara maju, yaitu sebesar 10-20 perkasus/100 anak per tahun sehingga menyebabkan lebih dari 5 juta kematian per tahun pada Balita. Menurut Riskesdas 2007, Pneumonia merupakan penyebab kematian kedua setelah Diare $(15,5 \%$ diantara semua balita) dan selalu berada pada peringkat 10 penyakit terbesar setiap tahun di setiap fasilitas kesehatan. Pneumonia balita merupakan salah satu indikator program pengendalian penyakit dan penyehatan lingkungan dalam rencana strategis Kemenkes tahun 2010-2014. Berdasarkan kelompok umur penduduk, period prevalence yang tinggi terjadi pada kelompok umur 1-4 tahun. Sejak tahun 2015, Puskesmas melakukan pemeriksaan dan tatalaksana Pneumonia melalui program Manajemen Terpadu Balita Sakit (MTBS). Selama beberapa tahun terakhir, 
cakupan pneumonia tidak pernah mencapai target nasional. Capaian pada tahun 2015 hanya sebesar $14,64 \%$ dari yang ditargetkan sebesar $20 \%$ pada seluruh kabupaten/kota yang ada (Profil Kesehatan Indonesia, 2015). Menurut laporan program pengendalian ISPA Dinas kesehatan kota Jambi tahun 2016, penemuan kasus Pneumonia paling banyak terjadi pada usia Balita (1.251 kasus) bila dibandingkan usia bayi sebanyak 269 kasus.

Anak yang mengalami gejala klinis Pneumonia harus mendapatkan penanganan secara cepat dan tepat. Orang tua dapat membawa anak dengan gejala klinis tersebut ke pusat pelayanan kesehatan terdekat seperti Puskesmas maupun Rumah sakit untuk mendapatkan penangan yang tepat sampai kondisinya membaik.

Masalah yang sering muncul pada anak dengan Pneumonia yang dibawa ke fasilitas kesehatan dan dirawat di rumah sakit adalah distress pernapasan yang ditandai dengan napas cepat, retraksi dinding dada, napas cuping hidung dan disertai stridor (WHO, 2009). Distress pernapasan merupakan kompensasi tubuh terhadap kekurangan oksigen, karena konsentrasi oksigen yang rendah, akan menstimulus syaraf pusat untuk meningkatkan frekuensi pernapasan. Jika upaya tersebut tidak terkompensasi maka akan terjadi gangguan status oksigenasi dari tingkat ringan hingga berat bahkan sampai menimbulkan kegawatan. Penurunan konsentrasi oksigen ke jaringan sering disebabkan karena adanya obstruksi jalan napas atas dan bawah karena peningkatan produksi sekret sebagai salah satu manifestasi adanya inflamasi pada saluran napas (Hockemberry \& Wilson, 2009).

Ketidakmampuan untuk mengeluarkan sekret merupakan kendala yang sering dijumpai pada anak usia bayi sampai dengan usia balita, karena pada usia tersebut reflek batuk masih lemah. Beberapa tindakan alternatif yang efektif untuk mengatasi masalah tersebut adalah fisioterapi dada, yang sering disebut sebagai fisioterapi konvensional yang meliputi postural drainage, vibrasi dan perkusi (Abdelbasset \& Elnegamy, 2015).

Alternatif lain untuk mengatasi masalah tidak efektifnya bersihan jalan napas pada anak yaitu dengan menerapkan teknik Pursed Lips Breahting (PLB). Teknik ini dapat digunakan sebagai alternatif untuk membantu mengatasi ketidakefektifan bersihan jalan napas pada anak (Tiep, Carter, Zachariah, Williams, Horak, et al., 2013). Selain itu, PLB bermanfaat untuk meningkatkan ekspansi alveolus pada setiap lobus paru, sehingga tekanan alveolus meningkat dan dapat membantu mendorong sekret pada jalan napas saat ekspirasi serta dapat menginduksi pola napas menjadi normal (Roberts, Schreuder, \& Watson, 2009). Pada akhirnya PLB diharapkan dapat meningkatkan status oksigenasi. Namun teknik PLB ini hanya dapat digunakan pada anak yang sadar dan mampu diajak kerjasama. Kelompok usia yang sudah mampu diajak kerjasama mulai dari anak usia prasekolah, karena pada usia ini anak sudah mampu menguasai bahasa dan memahami perintah sederhana selain kemampuan motoriknya yang sudah berkembang dari anak usia toddler (Hockenberry dan Wilson, 2009).

Teknik PLB dapat dianalogikan dengan aktivitas bermain seperti meniup balon/tiupan lidah, gelembung busa, bola kapas, kincir kertas, botol dan lain-lain (Hockenberry \& Wilson, 2009). Mekanisme yang digunakan menerapkan intervensi PLB, yaitu meningkatkan tekanan alveolus pada setiap lobus paru sehingga dapat meningkatkan aliran udara saat ekspirasi. Peningkatan aliran udara pada saat ekspirasi akan mengaktifkan silia pada mukosa jalan napas sehingga mampu mengevakuasi sekret keluar dari saluran 
napas. Tindakan ini sebagai salah satu upaya yang diduga mampu meningkatkan status oksigenasi.

Penelitian yang pernah dilakukan oleh Sutini (2011), tentang pengaruh aktivitas bermain meniup tiupan lidah terhadap status oksigenasi pada anak usia prasekolah dengan pneumonia di rumah sakit Islam Jakarta, menyimpulkan bahwa aktivitas bermain meniup tiupan lidah memiliki pengaruh yang signifikan terhadap peningkatan status oksigenasi pada anak (menurunkan ferekuensi Respiratory Rate/RR 8,1\%, meningkatkan Heart Rate/HR sebesar 6,25\%, dan meningkatkan $\mathrm{SaO} 2$ 5,43\%).

Hasil Studi pendahuluan yang didapatkan dari wawancara kepada perawat yang bertugas di Puskesmas Kebun Handil Kota Jambi, tatalaksana untuk anak dengan Pneumonia yaitu memberikan oksigen apabila anak sesak dan terapi antibiotik sesuai tatlaksana pneumonia menurut MTBS seperti amoksisilin. Tindakan mandiri keperawatan yang dilakukan seperti pemberian posisi dan mengobservasi frekuensi pernapasan anak, sementara tindakan seperti fisioterapi dada dan suction hampir jarang dilakukan karena memerlukan keterampilan khusus. Perawat belum pernah mendengar tentang keefektifan terapi dengan tiupan lidah dapat bermanfaat untuk meningkatkan status oksigenasi pada pasien gangguan pernapasan salah satunya pneumonia.

Berdasarkan penjelasan yang telah dikemukakan diatas, maka penulis tertarik untuk mengeksplorasi intervensi keperawatan berdasarkan evidence based practice yaitu dengan pursed lips breathing (PLB) melalui aktivitas bermain meniup "tiupan lidah" terhadap status oksigenasi pada anak usia prasekolah dengan pneumonia di wilayah kerja Puskesmas Kebun Handil Kota Jambi.

\section{METODE}

Penelitian ini menggunakan desain quasi-experimental dengan pretest-posttest control group design. Di dalam model ini sebelum dimulai perlakuan kedua kelompok dilakukan pretest dengan mengukur status oksigenasi awal dan selanjutnya diberi intervensi PLB lalu dilakukan pengukuran status oksigenasi (post-test), sedangkan pada kelompok kontrol diberi fisioterapi dada.

Responden yang terlibat dalam penelitian ini sebanyak 36 orang, yang terdiri dari 18 kelompok PLB dan 18 pada kelompok fisioterapi dada. Adapun kriteria inklusi sampel dalam penelitian ini sebagai berikut: 1) Anak usia pra sekolah 3-5 tahun dengan Pneumonia, 2) Tingkat kesadaran compos mentis dan kondisi stabil, 3) Mampu diajak kerjasama dan kooperatif,

4) Ibu atau keluarga anak bersedia menjadi responden.

Adapun prosedur yang dilakukan pada responden yang termasuk ke dalam kelompok intervensi PLB yaitu:

a) Memperkenalkan diri kepada pasien dan keluarga serta menjelaskan maksud dan tujuan tindakan yang dilakukan

b) Memberikan penjelasan tentang prosedur pelaksanaan tindakan, manfaat dan risikonya bahwa apa yang dilakukan tidak membahayakan anak

c) Setelah mendapatkan penjelasan dari peneliti, keluarga pasien diberikan kesempatan untuk menandatangani lembar persetujuan bila setuju anaknya dijadikan responden

d) Mengisi data pada lembar observasi yang telah disediakan

e) Setelah mengisi kuisioner, perawat mempersiapkan alat untuk prosedur penelitian yaitu mainan "tiupan lidah", respiratori rate timer, pulse oximeter dan thermometer.

f) Menjelaskan prosedur yang akan dilakukan pada pasien dan keluarga yaitu terlebih dahulu peneliti melakukan pengukuran suhu tubuh, frekuensi pernapasan, 
frekuensi nadi dan saturasi oksigen di lembar observasi.

g) Memberikan contoh cara meniup mainan "tiupan lidah". Cara meniup "tiupan lidah" sama dengan teknik PLB yaitu tarik napas dalam melalui hidung kemudian keluarkan udara melalui mulut yang dimonyongkan atau dikerutkan seperti mencucu, sampai "tiupan lidah" mengembang terisi udara sampai ujung. Beri kesempatan pasien untuk mengulang cara meniup "tiupan lidah" yang telah dicontohkan oleh perawat.

h) Mengatur posisi anak dengan posisi duduk/setengah duduk di kursi atau tempat tidur, memberikan mainan "tiupan lidah" untuk ditiup sebanyak 30 kali dalam rentang waktu 10-15 menit yang diselingi dengan napas biasa dengan ritme yang teratur, aktivitas bermain meniup tiupan lidah" ini dinilai hanya satu kali.

i) Mendampingi dan memotivasi anak selama melakukan aktivitas tersebut, memperhatikan kekuatan anak dalam meniup "tiupan lidah" dan mencatat kekuatan meniup dalam lembar observasi.

j) Melakukan pengukuran yang kedua terhadap RR, HR dan saturasi oksigen serta data karaketeristik anak sesaat setelah intervensi selesai dilakukan dan mencatat hasil pengukuran pada lembar observasi

k) Memberikan pujian pada anak dan terminasi pada keluarga atas kerjasamanya.

\section{HASIL}

Data yang telah dikumpulkan diolah dengan analisis univariat dan bivariat. analisis univariat menggambarkan karakteristik responden penelitian. Adapun hasilnya dapat dijelaskan sebagai berikut:

Tabel 1.1 Distribusi responden menurut jenis kelamin $(n=36)$

\begin{tabular}{lcccc}
\hline Kelompok & Laki-laki & $\%$ & $\begin{array}{c}\text { Perempu } \\
\text { an }\end{array}$ & $\%$ \\
Kontrol & 10 & 55,6 & 8 & 44,4 \\
Intervensi & $\underline{11}$ & $\underline{61,1}$ & $\underline{7}$ & $\underline{38,9}$ \\
\hline
\end{tabular}

Tabel 1.2 Karakteristik responden menurut usia, berat badan, kekuatan meniup, dan lama sakit $(n=36)$

Dari tabel diatas dapat digambarkan sebagian besar responden berjenis kelamin laki-laki, baik pada kelompok intervensi maupun kelompok kontrol. Uji normalitas dan homogenitas telah dilakukan pada kedua kelompok. Dapat disimpulkan bahwa ada kesetaraan

\begin{tabular}{|c|c|c|c|c|c|}
\hline Variabel & Kelompok & Mean & $\begin{array}{c}\text { Standar } \\
\text { deviasi }\end{array}$ & $\begin{array}{l}95 \% \\
\text { CI }\end{array}$ & Pvalue \\
\hline Usia & $\begin{array}{c}\text { Kontrol } \\
\text { Intervensi }\end{array}$ & $\begin{array}{l}4,36 \\
4,04\end{array}$ & $\begin{array}{l}0,74 \\
0,81\end{array}$ & $\begin{array}{c}3,99- \\
4,73 \\
3,64- \\
4,44\end{array}$ & 0,474 \\
\hline $\begin{array}{l}\text { Berat } \\
\text { badan }\end{array}$ & $\begin{array}{l}\text { Kontrol } \\
\text { Intervensi }\end{array}$ & $\begin{array}{l}16,1 \\
14,6\end{array}$ & $\begin{array}{l}1,9 \\
2,3\end{array}$ & $\begin{array}{c}15,1- \\
17 \\
13,4- \\
15,7 \\
\end{array}$ & 0,012 \\
\hline $\begin{array}{c}\text { Kekuatan } \\
\text { meniup }\end{array}$ & $\begin{array}{c}\text { Kontrol } \\
\text { Intervensi }\end{array}$ & $\begin{array}{l}14,2 \\
13,3\end{array}$ & $\begin{array}{l}0,73 \\
1,53\end{array}$ & $\begin{array}{c}13,9- \\
14,6 \\
12,5- \\
14 \\
\end{array}$ & 0,489 \\
\hline $\begin{array}{c}\text { Lama } \\
\text { sakit }\end{array}$ & $\begin{array}{l}\text { Kontrol } \\
\text { Intervensi }\end{array}$ & $\begin{array}{l}2,9 \\
4,4\end{array}$ & $\begin{array}{l}1,23 \\
0,74\end{array}$ & $\begin{array}{c}2,28- \\
3,5 \\
3,99- \\
4,73 \\
\end{array}$ & 0,075 \\
\hline
\end{tabular}

antara kelompok kontrol dan kelompok intervensi dalam hal karakteristik anak (responden).

Tabel 1.3 Perbedaan status oksigenasi: RR sebelum dan sesudah diberikan PLB pada kelompok kontrol dan kelompok intervensi $(n=36)$

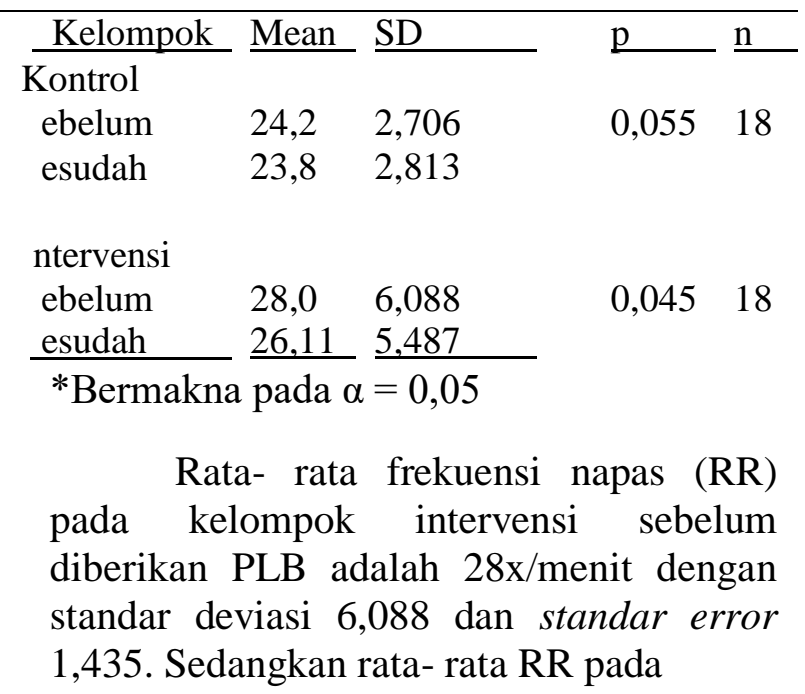


kelompok intervensi sesudah diberikan PLB adalah 26,11 x/menit dengan standar deviasi 5,487dan standar error 1,293. Terlihat nilai mean perbedaan RR antara sebelum dan sesudah diberikan PLB, pada kelompok intervensi adalah 1,89 dan hasil uji statistik didapatkan nilai $\mathrm{p}$ value sebesar 0,045, maka dapat disimpulkan bahwa pada alpha $5 \%$ terdapat perbedaana. RR yang signifikan antara sebelum dan sesudah diberikan PLB pada kelompok intervensi dan pemberian PLB berpengaruh terhadap peningkatan sebesar 1,89x/menit RR pada anak yang mengalami Pneumonia.

Tabel 1.4 Perbedaan status oksigenasi: saturasi oksigen sebelum dan sesudah diberikan PLB pada kelompok kontrol dan kelompok intervensi $(n=36)$

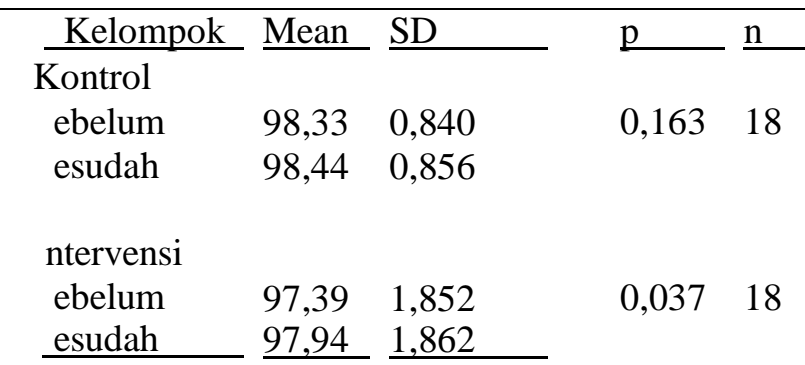

*Bermakna pada $\alpha=0,05$

Rata- rata suhu pada kelompok intervensi sebelum diberikan PLB adalah 97,39\% dengan standar deviasi 1,852 dan standar error 0,436. Sedangkan rata- rata saturasi oksigen pada kelompok intervensi sesudah diberikan PLB adalah 97,94\% dengan standar deviasi 1,862 dan standar error 0,663 . Terlihat nilai mean perbedaan suhu antara sebelum dan sesudah diberikan PLB pada kelompok intervensi adalah 0,55 dan hasil uji statistik didapatkan nilai $\mathrm{p}$ value sebesar 0,037, maka dapat disimpulkan bahwa pada alpha 5\% terdapat perbedaan saturasi oksigen yang signifikan antara sebelum dan sesudah diberikan PLB pada kelompok intervensi. Pemberian PLB berpengaruh terhadap peningkatan sebesar $0,55 \%$ status oksigenasi yaitu terhadap saturasi oksigen pada anak yang mengalami Pneumonia.

\section{PEMBAHASAN}

Karakteristik responden yang terlibat dalam penelitian ini meliputi jenis kelamin, usia, berat badan, kekuatan meniup dan lama sakit.

Jenis Kelamin

Sebagian besar jenis kelamin responden laki-laki pada kedua kelompok. Cara pengambilan sampel dalam penelitian ini yaitu Purposive Sampling sehingga kemungkinan jumlah kelompok terbanyak berada pada salah satu jenis kelamin mungkin saja terjadi. Pada saat pengambilan data, lebih banyak anak lakilaki yang menderita pneumonia bila dibandingkan dengan anak perempuan. Temuan yang ada dilapangan sesuai dengan teori yang di kemukakan olah Hockenberry dan Wilson (2009) yang menyebutkan bahwa anak laki-laki di United State lebih berisiko mengalami morbilitas dan mortalitas bila dibandingkan dengan anak perempuan. Hal ini dapat disebabkan oleh beberapa faktor, salah satunya karakteristik anak laki-laki yang lebih sering mengalami cedera bahkan dapat menyebabkan kematian berjumlah 1006 orang, sedangkan anak peremupan berjumlah 758 orang.

b. Usia

Rerata usia anak pada kelompok kontrol yaitu 4,36 tahun dan 4,04 tahun pada kelompok intervensi. Di Kanada, penyebab anak mengalami hospitalisasi dan bahkan berdampak pada kematian yaitu dikarenakan penyakit, diantaranya influenza dan pnemonia. Penyakit ini berhubungan dengan angka cakupan imunisasi. Sebastian, Skowronski, Chong, Dhaliwal, Brownstein (2008) menyebutkan bahwa kelompok usia anak yang lebih berisiko mengalami Pneumonia dan Influenza terjadi pada kelompok usia yang lebih kecil dan lebih besar dari pada usia sekolah. Hal ini berarti anak di usia prasekolah (3-5 tahun) cenderung lebih 
berisiko untuk menderita penyakit Pneumonia.

Berdasarkan pedoman pelaksanaan stimulasi, deteksi dan intervensi dini tumbuh kembang anak (Kemenkes RI, 2016). Pada masa anak usia prasekolah pertumbuhan berlangsung stabil. Terjadi perkembangan dengan aktivitas jasmani yang bertambah dan meningkatnya keterampilan dan proses berfikir. Memasuki masa prasekolah, anak mulai menunjukkan keinginannya, seiring dengan pertumbuhan dan perkembangannya. Pada masa ini selain lingkungan di dalam rumah maka lingkungan di luar rumah diperkenalkan. Anak mulai senang bermain diluar rumah. Hal ini berisiko bagi anak untuk terpapar dan tertular penyakit infeksi seperti Influenza dan Pneumonia dari temanteman sepermainan dan lingkungan tempat anak bermain diluar rumah.

\section{c. Berat Badan}

Rerata berat badan anak pada kelompok kontrol yaitu $16,1 \mathrm{~kg}$ dan $14,6 \mathrm{~kg}$ pada kelompok intervensi. Jika dilihat dari data hasil penelitian didapatkan bahwa berat badan anak kelompok kontrol lebih tinggi dibanding anak kelompok intervensi $(16,1$ $\mathrm{kg} ; 14,6 \mathrm{~kg}$ ). Hal ini menunjukkan ada kemungkinan bahwa sakit pneumonia yang diderita dapat mempengaruhi berat badan anak.

Jika berat badan terus menurun karena kondisi sakit anak akan dapat mempengaruhi tumbuh kembang anak. Pelaksanaan kegiatan deteksi dini tumbuh kembang anak (DDTK) di Puskesmas memberikan pelayanan pemeriksaan kesehatan, pemantauan berat badan dan deteksi dini tumbuh kembang (Kemenkes RI, 2016).

Berat badan merupakan salah satu penentu status gizi pada anak. Untuk pemantuan pertumbuhan dengan menggunakan berat badan menurut umur dilaksanakan secara rutin di posyandu setiap bulan. Apabila ditemukan anak dengan berat badan tidak naik dua kali berturut-turut atau anak dengan berat badan dibawah garis merah, kader akan merujuk ke petugas kesehatan untuk dilakukan konfirmasi dengan menggunakan indikator berat badan menurut panjang badan/tinggi badan.

\section{d. Kekuatan Meniup}

Rerata kekuatan meniup anak pada kelompok kontrol yaitu 14,2 cm dan 13,3 $\mathrm{cm}$ pada kelompok intervensi. Kekuatan meniup pada anak akan terkait dengan kemampuan anak untuk melakukan napas dalam. Faktor fisiologis yang menyebabkan gangguan pernapasan meliputi hiperventilasi, hipoventilasi dan hipoksia. Anak yang tidak mampu untuk bernapas dalam mengindikasikan adanya gangguan pada sistem pernapasannya. Proses fisiologi lain yang mempengaruhi proses oksigenasi adalah perubahan yang mempengaruhi kapasitas darah untuk membawa oksigen, seperti anemia, peningkatan kebutuhan metabolisme (seperti demam, infeksi) dan perubahan yang mempengaruhi gerakan dinding dada atau sistem saraf pusat (Ball, Bindler dan Cowen, 2010).

\section{e. Lama Sakit}

Rerata lama sakit pada kelompok kontrol yaitu 2,9 hari dan 4,4 hari pada kelompok intervensi. Gangguan pernapasan merupakan penyebab tersering anak sakit dan di rawat di rumah sakit. Penyakit ini dapat berupa penyakit ringan dan tidak akut hingga kondisi yang mengancam jiwa. Penyakit kronik dapat mempengaruhi kualitas hidup, tetapi infeksi akut atau berulang yang sering terjadi, juga dapat mengganggu kesejahteraan beberapa anak (Kyle dan Carman, 2016).

Orangtua biasanya dapat mengalami kesulitan menentukan tingkat keparahan kondisi anak mereka dan mencari bantuan kesehatan sangat dini dalam perjalanan penyakit tersebut. Pada penelitian ini di temukan rerata orang tua mencari pertolongan ke tenaga kesehatan bukan di hari pertama anak sakit tetapi setelah 3-4 hari setelah sakit (2,9 hari pada kelompok 
kontrol dan 4,4 hari pada kelompok intervensi).

Selanjutnya akan dibahas hasil analisis bivariat yaitu status oksigenasi sebelum dan sesudah diberikan PLB. pada penelitian status oksigenasi yang akan dibahas yaitu frekuensi pernapasan dan saturasi oksigen.

Frekuensi Pernapasan (RR) sebelum dan sesudah perlakuan. Rerata pada kelompok intevensi sebelum di berikan PLB adalah 28x/menit dan standar deviasi 6,088 dan standar error 1,435. Sedangkan pada rata-rata $R R$ pada kelompok intervensi sesudah diberikan PLB adalah 26,11 x/menit dengan standar deviasi 5,487 dan standar error 1,293 . Terlihat nilai mean perbedaan RR antara sebelum dan sesudah di berikan PLB pada kelompok intervensi adalah 1,29 dan hasil uji statistik didapatkan nilai $\mathrm{p}=0,045$; maka dapat di simpulkan bahwa pada alpha 5\% terdapat perbedaan $R R$ yang signifikan antara sebelum dan sesudah di berikan PLB pada anak kelompok intervensi. Sehingga pemberian PLB berpengaruh terhadap peningkatan frekuensi pernapasan (RR) sebesar $1,89 \mathrm{x} /$ menit pada anak yang mengalami Pneumonia.

Kegiatan anak bermain dengan tiupan lidah selain menyenangkan pada anak yang sedang sakit juga bermanfaat bagi anak untuk melatih napas dalam. Karena setiap kali anak akan meniup, anak akan berusah untuk menarik napas sampai batas kemampuannya (seoptimal mungkin) dan berusaha kembali untuk meniupkan udara sekeras-kerasnya.

Jika dilihat dari panjangnya anak meniup tiupan lidah yaitu rerata kekuatan $13,3 \mathrm{~cm}$ maka terlihat bahwa anak mengalami gangguan pernapasan ringan, karena panjang maksimal dan mainan tiupan lidah yang diberikan saat proses penelitian adalah $15 \mathrm{~cm}$ maka rerata anak belum mampu meniup secara maksimal. Minimal itupan 12,5 $\mathrm{cm}$ dan maksimal tiupan $14 \mathrm{~cm}$. Gangguan pernapasan umum terjadi pada anak dapat berupa akut, mengancam jiwa dan kronis.

Sementara itu usia rerata responden 3-5 th biasanya sudah dalam kondisi kooperatif dan sangat meyukai kondisi bermain dengan menggunakan alat dan sangat menyukai alat bermain yang di tiup dan mengeluarkan bunyi keras. Di dukung dengan jenis kelamin responden yang sebagian besar adalah laki-laki yang biasanya lebih aktif dan agresif pada saat diminta untuk meniup.

Bayi dan anak kecil menghirup udara yang lebih kecil, dan menghembuskan oksigen yang relatif besar. Bayi dan anak kecil mempunyai lebih sedikit alveoli oleh karena itu, permukan alveolus sedikit yang merupakan tempat pertukaran gas terjadi. Faktor-fakotr ini, bersama-sama dengan tingkat metabolik yang lebih tinggi, bersifat mempengaruhi peningkatan frekuensi pernapasan pada bayi dan anakanak. Melihat keterangan diatas seharusnya pada anak responden dalam kondisi pernapasan yang baik sehingga dapat meniup tiupan lidah sampai batas tertinggi yaitu $15 \mathrm{~cm}$. Kisaran rentang RR responden sebelum dilakukan intervensi yaitu 20-41 dengan rata-rata $28 \mathrm{kali} / \mathrm{menit}$. Sedangkah kisaran rentang sesudah intervensi yaitu 18-39 dengan rata-rata 26,1 kali/menit. Perbedaan yang menunjukkan adanya perubahan menjadi patokan bahwa kegiatan terapi dengan meniup tiupan lidah memberikan pengaruh yang signifikan (nilai $\mathrm{p}=0,47$ ). Peningkatan aktivitas yang dilakukan oleh anak berdampak pada terjadinya peningkatan frekuensi pernapasan dan kedalamannya.

Paru-paru mempunyai 2 fungsi utama yaitu menyediakan oksigen bagi tubuh dan mengeluarkan $\mathrm{CO}_{2}$ serta untuk mempertahankan keseimbangan asam basa tubuh. Menurut Garrod dan Matheison (2012), PLB merupakan bagian dari latihan napas yang diperlukan untuk pasien yang mengalami gangguan pada sistem pernapasan, karena PLB memberikan efek yang baik terhadap sistem pernapasan, 
diantaranya adalah; menyehatkan ventilasi, membebaskan udara yang terperangkap dalam paru-paru, menjaga jalan napas tetap terbuka lebih lama dan mengurangi kerja napas, memperpanjang waktu ekshalasi yang kemudian memperlambat frekuensi napas, meningkatkan pola napas dengan mengeluarkan udara lama dan memasukkan udara baru ke dalam paru, menghilangan sesak napas dan meningkatkan relaksasi.

PLB yang di lakukan dengan teknik meniup tiupan lidah maka akan dapat membantu untuk mengekspansi alveolus pada semua lobus agar meningkat, dan tekanan di dalamnya pun menjadi meningkat. Tekanan yang tinggi dalam alveolus dan lobus dapat mengaktifkan silia pada saluran napas untuk mengevakuasi sekret keluar dari jalan napas berarti akan menurunkan tahanan jalan napas dan meningkatkan ventilasi yang pada akhirnya memberikan dampak terhadap proses perfusi oksigen ke jaringan.

Pada penelitian ini dapat disimpulkan bahwa pentingnya untuk melakukan napas dalam pada anak yang mengalami gangguan pernapasan seperti pada pasien Pneumonia dan dalam hal ini latihan napas dalam yang di ajarkan serta dilakukan pada responden adalah dengan memberikan terapi tiupan lidah dalam bentuk permainan sehingga anak akan merasa tetap bermain tanpa menyadari bahwa dia sedang menjalani proses terapi pernapasan.

Penting sekali bagi petugas kesehatan untuk dapat tetap melaksanakan terapi sesuai dengan kondisi anak tanpa mendapat penolakan yang cukup berarti dari anak. Hal ini juga dapat dijelaskan pada orang tua agar dapat melaksanakannya dirumah atau diarea yang disukai oleh anak. Kreativitas tenaga kesehatan dalam memilihkan model-model kegiatan terapi dapat menunjang keberhasilan dari itndakan kesehatan yang diberikan.

Rerata saturasi oksigen pada kelompok intervensi sebelum diberikan
PLB adalah 97,39 dengan standar deviasi 1,852 dan standar error 0,436 . Sedangkan rata-rata saturasi oksigen pada kelompok intervensi sesudah diberikan PLB adalah 97,94 dengan standar deviasi 1,862 dan standar error 0,663. Terlihat nilai mean perbedaan saturasi antara sebelum dan sesudah diberikan PLB pada kelompok intervensi yaitu 0,55 dan hasil uji statistik didapatkan nilai $\mathrm{p}=0,037$, maka dapat disimpulkan bahwa pada alpha 5\% terdapat perbedaan saturasi oksigen yang signifikan antara sebelum dan sesudah di berikan PLB pada kelompok intervensi.

Faktor fisiologis yang menyebabkan gangguan pernapasan meliputi hiperventilasi, hipoventilasi dan hipoksia. Proses fisiologi lain yang mempengaruhi proses oksigenasi adalah perubahan yang mempengaruhi kapasitas darah untuk membawa oksigen.

Menurut Hockenberry dan Wilson (2009), pengukuran saturasi oksigen kapiler yang kontinu dapat dilakukan dengan menggunakan oksimetri kutaneus. Keuntungan pengukuran oksimetri yaitu mudah dilakukan, tidak invasif dan mudah diperoleh (Bowden dan Greenberg,2010). Hal ini juga yang peneliti lakukan pada penelitian ini yaitu mengukur saturasi oksigen dengan oksimetri.oksimetri nadi sangat sensitive terhadap hiperoksia karena hemoglobin mendekati saturasi 100\% untuk hasil pengukuran $\mathrm{SaO}_{2}$ yang lebih dari $100 \mathrm{mmHg}$.

Dalam aktivitas meniup yang dilakukan sebagai terapi bermain pada responden anak, anaklah yang berperan. Peneliti tetap memperhatikan keadaan umum anak serta memberikan pujian apabila anak dapat melakukan permainan dengan benar. Hal ini dilakukan dan anak tidak merasa takut bahkan menyukainya.

Walaupun nilai saturasi oksigen sebelum dan sesudah di lakukan PLB masih dalam batas normal namun tampak perubahan nilai saturasi kearah yang lebih baik setelah dilakukan PLB. Hal ini menunjukkan bahwa tindakan PLB 
membawa pengaruh yang positif pada nilai saturasi oksigen anak.

Pada Panduan Manajemen Terpadu Balita Sakit (MTBS) tahun 2015 pada anak yang dicurigai menderita pneumonia sebaiknya dilakukan pemeriksaan dengan menggunakan Pulse Oximetri untuk menilai saturasi oksigen pada anak, hitung napas dalam 1 menit; melihat apakah ada tarikan dinding kedalam, serta memperhatikan adanya bunyi napas yang tidak normal. Semua pemeriksaan tersebut harus dilakukan pada anak dalam kondisi tenang.

Gejala yang ditunjukkan pada nilai saturagi oksigen $<90 \%$ mengindikasikan adanya pneumonia berat. Pada kelompok kontrol rata-rata nilai saturasi setelah PLB $98,44 \%$ dan $97,94 \%$ nilai saturasi oksigen pada kelompok intervensi. Nilai ini menjadi berarti setelah dibandingkan saturasi oksigen sebelum intervensi dan sesudah intervensi pada kelompok intervensi.

Porsi oksigen yang cukup didalam tubuh anak sangat penting karena oksigen dibutuhkan untuk mempertahankan kehidupan. Sistem pernapasan dan jantung mempunyai peranan penting dalam menyuplai kebutuhan oksigen keseluruh tubuh. Tindakan yang dilakukan pada PLB dan meminta anak untuk meniup tiupan lidah dapat membantu transport gasyang berisikan oksigen keseluruh tubuh. Hal ini dapat menguatkan otot jantung dengan cra latihan meniup sehingga fungsi jantung dapat lebih optimal.

\section{KESIMPULAN}

Terapi Pursed lips breathing efektif meningkatkan status oksigenasi pada anak usia prasekolah yang mengalami Pneumonia meliputi: suhu, frekuensi pernapasan, frekuensi nadi, dan saturasi oksigen. Gambaran karakteristik responden yaitu mayoritas berjenis kelamin laki-laki baik pada kelompok kontrol maupun intervensi. Status oksigenasi responden sesudah diberikan terapi pursed lips breathing mengalami peningkatan sebesar 0,2 pada variabel suhu, 1,89 pada frekuensi pernapasan, 4,95 pada frekuensi nadi, dan 0,55 pada saturasi oksigen. Status oksigenasi pada kelompok intervensi memiliki rerata lebih tinggi dibandingkan dengan kelompok kontrol.

\section{UCAPAN TERIMA KASIH}

1. Ka. Puskesmas Kebon Handil Kota Jambi berserta staf

2. Semua pihak yang telah membantu

\section{DAFTAR PUSTAKA}

Abdelbasset, W.K.M., Elnegamy, T.E.H. (2015). Effect of chest physical therapy on pediatrics hospitalized with pneumonia. International Journal of Health and Rehabilitation Science, 4(4), 219226.

Alsagaff, H., \& Mukty, A. (2010). Dasardasar ilmu penyakit paru. (Edisi 10). Surabaya: Airlangga University Press.

Ball, J.W., Bindler, R.C., \& Cowen, K.J. (2010). Child health nursing, partnering withchildren \& families. (2nd ed). New Jersey:Pearson Education inc.

Bhatt, S.P., Luqman-Arafath, T.K., Gupta, A.K., Mohan, A., Stoltzfus, J.C., dey.,... \& Guleria, R. (2012). Volitional pursed lips breathing in patients with stable cronic obstructive pulmonary disease improves exercise capacity. Cronic Respiratory Disease, 10(1), 5-10

Bowden, V.R., \& Greenberg, C.S. (2010). Children and their families: the continuum of care. ( $2^{\text {nd }}$ edition). Philadelphia: Lippincott Williams \& Wilkins. 
NERS: Jurnal Keperawatan, Volume 14, No. 2, Oktober 2018, (Hal. 92-101)

Driver, C. (2012). Pneumonia part I: Pathology, presentation \& prevention. British Journal of Nursing, 21(2), 103-106.

Fiquis, M.R., Gine-Gariga, M., Ruqeles, C.G., Perrota, C., \& Vilano, J. (2016). Chest physiotherapy for acute bronchiolitis in pediatric patients between 0 and 24 mounts old. The Cocrane Library, issue 2

Hockenberry, M.J., \& Wilson, D. (2009). Wong's essentials of pediatric nursing. ( $8^{\text {th }}$ edition). St. Louis Missouri: Elsevier Mosby.

Lisy, K. (2014). Critical care: Chest Physiotherapy for pneumonia in children. AJN. 114(5), 16.

Lukrafka, J.L., Fuchs, S.C., Fischer, G.B., Flores, J.A., Fachel, J.M., CastroRodriguez, J.A. (2012). Chest physiotherapy in paediatric patients hospitalized with communityacquired pneumonia: A randomized clinical trial. Arc Dis Child, 00, 1-5, doi: 10.1136/archdishchild-2012302279

Paul, S., O’Callaghan, C., \& McKee, N. (2011). Effective management of lower respiratory tract infections in childhood. Nurs Child Young People, 23(9), 27-34.

Rackini, C.M., Samundeeswary, V., \& Beulah, H. (2014). Effectiveness of blow bottles exercise on respiratory status among children with lower respiratory tract infections admitted in pediatric ward at selected hospital. Journal of Science, 4(10), 649-652

Santos, C.I.S. (2009). Respiratory physiotherapy in children with community-acquired pneumonia. Revue Canadienne de la therapie respiratoire.
Sutini, T. (2011). Pengaruh aktivitas bermain meniup tiupan lidah terhadap status oksigenasi pada anak usia prasekolah dengan pneumonia di Rumah sakit Islam Jakarta. Tesis FIK-UI.

Tiep, B., Carter, R., Zachariah, F., Williams, A.C., Horak, D., Barnett, M.,.. \& Dunham, R. (2013). Oxygen for end-of-life lung cancer care: Managing dyspnea and hypoxemia. Expert Review of Respiratory Medicine, 7(5), 479490.

Visser, F.J., Ramlal, S., Dekhuijzen., \& Heijdra, Y.F. (2010). Pursed lips breathing improves inspiratory capacity in cronic obstructive pulmonary disease. Respiration, 81, 372-378. doi:10.1159/000319036

World Health Organization. (2009). Buku saku: Pelayanan kesehatan anak di rumah sakit. Jakarta: WHO. 